\title{
The Flying Newspapermen and the Time-Space of Late Colonial Nigeria
}

\author{
LESLIE JAMES \\ Queen Mary University of London
}

It is 7:00 a.m. on a given morning in Lagos in 1938. Civil servants, public works officials, bookkeepers and clerks - the literate force who made up the reading public of Nnamdi Azikiwe's fledgling newspaper, the West African Pilot - open their crisp daily issue to page three and are greeted by Tom Tinkle. "Good morning Citizens. Tap, tap, tap, tap, can you hear me?" Tinkle taps again. "Citizens of Renascent Africa, will you let Tinkle in, or will you leave Tinkle to stand out?" Today Tinkle splits himself into two, leaving "small Tinkle the spy" in Port Harcourt before jumping "up into my zeppelin" and flying to Kano. "On the roof of the office of the Kano Native Administration Electricity Supply, Tinkle sits. Listen Citizens, Tinkle speaks." Today Tinkle is unhappy with the rate of pay that African staff members receive at the Electric supply. Yesterday, Tinkle "jump[ed] from roof to roof" before "admiring the Crown Counsel, Mr. C.N.S. Pollard, and quickly he drops from the roof and gets into his pocket." ${ }^{2}$ Tomorrow, Tinkle will "divide himself into multitudinous bits of small flying insects" in order to enter the cemetery and confront "non-Africans" who live in the "Club of the Dead." 3

Acknowledgments: The archival research and writing of this article were conducted during a Leverhulme Early Career Fellowship. I am grateful to the Leverhulme Trust for the opportunity to complete this work. Joseph Ayodokun was an invaluable guide to research in Ibadan, and the expertise of John Adegoke of the National Archives Nigeria was essential to my interaction with some of the newspapers discussed. I am also grateful to the group of scholars who met in Maropeng, South Africa for a workshop on African Print Cultures, and to Derek Peterson and Isabel Hofmeyr for their early comments on this draft. Karin Barber provided invaluable comments on another version of this paper, and the anonymous readers for $C S S H$ all provided comments that immensely improved the paper.

1 Tom Tinkle, "Here, There, and Yonder," West African Pilot, 1 Oct. 1938: 7.

2 Ibid., 3 Aug. 1938: 7.

3 Ibid., 19 Aug. 1938: 7. 
From July 1938 to June 1941, readers of the West African Pilot were treated to the perambulations and ruminations of Tom Tinkle's "Here, There, and Yonder," a semi-regular comment column written in the third person with biting satire and critique, elaborated usually through Tinkle's flights around Lagos and surrounding provinces. A decade later readers of another "Zik press" newspaper, the Comet, encountered a similar mode of news and comment by-way-of travel in the column of Roving Hobo when he was "deputized" by the "Hobo trust" to go "globe-trotting." I am interested in how location, space, and time were simultaneously grounded and overcome in news reports by this series of pseudonymous columnists who wrote for a press sphere that claimed to hold the largest circulation in West Africa in the 1930s and 1940s. Tom Tinkle travelled around the colony, flying and shapeshifting in order to expose the abuses of British colonial administrators, European commercial agents, and black Africans who were seen to ally with these agents. Roving Hobo extended this model to the global, applying his transcendent powers and his connections with African diaspora leaders to an interconnected critique of the British colonial regime in Nigeria and international politics. Both also used their powers of mobility to enter and disrupt the chronology of modernity's historical time. These flying newspapermen, I aim to show, served as not only a tool for exploring diverse geographic spaces, but also a metaphor for thinking about the time-space Nigerians occupied in a period where questions of colonial administration, sovereignty, and representation were hotly contested. Their rendering of the present exemplifies how "alternative languages of claim-making," to use Frederick Cooper's oft-repeated phrase, required not only a variety of competing ideas but also divergent ways of speaking about time and place.

Time and space, history and historicity have figured prominently in scholarship over the past two decades. Recent studies of Indian, African, and Caribbean political thinkers and leaders emphasize the era leading up to and immediately after decolonization as one saturated with awareness of time and history. Manu Goswami argues that in the 1920s and 1930s, as colonized intellectuals sought to stake their position in the face of a reformed but renewed imperial mission and Wilsonian internationalism, colonial internationalism "offered a future-oriented conception of politics that affirmed what was new in an unstable present." India's preeminent statesman, Jawaharlal Nehru, was both a politician and a historian who viewed political action as taking place "within an unstable and indeterminate present, a space of competing temporalities on which the past exerted influence and the future exerted demands." His state-building projects sought to "order time" against this indeterminate and

\footnotetext{
4 Manu Goswami, "Imaginary Futures and Colonial Internationalisms," American Historical Review 117, 5 (Dec. 2012): 1461-85, 1463.
} 
unstable present. ${ }^{5}$ In the same era, Aimé and Suzanne Césaire in Martinique and, to a certain extent, Léopold Sédar Senghor in Senegal, sought strategies for reckoning with the "untimeliness" of the French postwar era, a period that Gary Wilder characterizes as saturated with the sense of temporal confusion where past, present, and future did not align, where time appeared disjointed. ${ }^{6}$ For Wilder, Césaire "played with the untimely character of politics, and the political character of time, in the age of decolonisation."

Much recent scholarship about colonial ideas of time and history has been animated by Rienhart Koselleck's theory of "multiple temporalities." Koselleck's work provided a map for analyzing history as not periodization but a series of layers of "historical times." He urged historians to analyze not only the past's "spaces of experience" but also peoples" "horizons of expectation."7 That is, what were the spheres of action that people envisioned themselves to be existing within? Futurist narratives, as a palliative to historians' obsession with the past, have gained prominence. ${ }^{8}$ Cooper has taken up this approach by attending to some of history's "paths not taken." This has prompted renewed debate about the extent to which alternate political forms to the nation-state, especially federal versions of governance, which Nigerians also debated at this time, were actually possible in the era of decolonization. ${ }^{9}$ Cooper has also encouraged scholars to analyze "modernity" as a device for making claims in colonial society, and thus to pay greater attention to the different ways that people articulated their demands. ${ }^{10}$ Emma Hunter has shown how vernacular newspapers in late colonial Tanzania were a place where people developed shared languages for reflecting upon social and political change. This did not involve just one narrative about "progress," a more commonly used word than "modernity" at the time, but rather a variety of narratives that articulated aspiration and uncertainty about the implications of change. ${ }^{11}$ Harri Englund emphasizes the sense of experimentation underway in Zambian newspapers during this same era, which certainly complements the creative outlet visible in West African newspapers. Englund's analysis shows

5 Sunil Purushotham, "World History in the Atomic Age," Modern Intellectual History (2016): 1-31, 3 (accessed 1 Apr. 2016), doi 10.1017/S1479244316000093.

${ }^{6}$ Gary Wilder, Freedom Time: Negritude, Decolonisation, and the Future of the World (Durham: Duke University Press, 2015), 37-40.

7 Helge Jordheim, "Against Periodization: Koselleck's Theory of Multiple Temporalities," History and Theory 51 (May 2012): 151-71.

8 David C. Engerman, "Introduction: Histories of the Future and the Futures of History," American Historical Review 117, 5 (Dec. 2012): 1402-10; Goswami, "Imaginary Futures,” 1461-85.

9 Musab Younis, “Against Independence," London Review of Books 39, mp/ 13 (29 June 2017): 27-28; Samuel Moyn, “Fantasies of Federalism," Dissent (Winter 2015), https://www.dissentmagazine.org/article/fantasies-of-federalism (accessed 28 Jan. 2015).

${ }^{10}$ Frederick Cooper, Colonialism in Question (Berkeley: University of California Press, 2005), 234

11 Emma Hunter, Political Thought and the Public Sphere in Tanzania (Cambridge: Cambridge University Press, 2015), 35-64. 
that Zambians articulated a number of "emergent possibilities" that cannot be easily relegated either to anti-colonial nor pro-colonial positions. ${ }^{12}$

This latest work on African newspapers notwithstanding, a fundamental question remains that I hope to engage here: how could the imagined potential that people expected coexist with concrete daily life? Put another way, how could horizons of expectation, which were different from existing norms, be expressed within a real existing present?

We know that in Euro-American intellectual history, "space" as outer space became, around the mid-twentieth century, a fundamental means of interrogating our earth-bound humanity in relation to a "global" or planetary outlook. ${ }^{13}$ In Black American imaginaries after the $1970 \mathrm{~s}$, the science fiction and fantasy, astronauts, rockets, and space of Afro-futurism serve as one aesthetic for a longer history of surrealist creativity by African and African diaspora poets, artists, and political agitators. This long history of surrealist creativity includes, for example, the recent discovery of a short story by the profoundly influential intellectual and activist W.E.B. Du Bois in which he writes of a black sociologist who creates a "megascope" machine in order to see across time and space. ${ }^{14}$ Indeed, we should take as one signal the fact that both Nigerian columnists introduced above appeared in newspapers named after unearthly flying objects. The Comet, the newspaper that printed Roving Hobo, was also the title of one of Du Bois's better-known science fiction stories, published in 1920.

Fantastical imaginaries were a means of making sense of an absurd reality. If we return to earthbound spaces, John Parker has shown how supernatural imaginings, including shape-shifting from human to animal form, were part of expressing the anxieties of cross-cultural interaction on the coast of West Africa not solely as part of the European colonial encounter, but also as part of a longer history of power relations between Africans. ${ }^{15}$ The shape-shifting "man-leopard murders" in 1940s southeastern Nigeria, David Pratten has shown, mixed together a number of complex variables at play in wartime Calabar, which combined Annang epistemologies of the past, the increased

12 Harri Englund, “Anti Anti-Colonialism: Vernacular Press and Emergent Possibilities in Colonial Zambia," Comparative Studies in Society and History 57, 1 (2015): 221-47.

13 Benjamin Lazier, "Earthrise; or, The Globalisation of the World Picture," American Historical Review 116, 3 (June 2011): 602-30.

14 Robin Kelley, Freedom Dreams: The Black Radical Imagination (Boston: Beacon Press, 2002); Mark Dery, "Black to the Future: Interviews with Samuel R. Delany, Greg Tate, and Tricia Rose," in Mark Dery, ed., Flame Wars: The Discourse of Cyberculture (Durham: Duke University Press, 1994), 179-222; Franklin Rosemont and Robin Kelley, eds. Black Brown, and Beige: Surrealist Writings from Africa and the Diaspora (Austin: University of Texas Press, 2009); W.E.B. Du Bois, "The Princess Steel," introduction by Adrienne Brown and Britt Rusert, PMLA 13, 3 (May 2015): 819-29.

15 John Parker, "Northern Gothic: Witches, Ghosts and Werewolves in the Savanna Hinterland of the Gold Coast, 1900s-1950s," Africa 76, 3 (2006): 352-80. 
bureaucracy that accompanied the "Native Administration" reforms after 1931, and colonial policing and surveillance. ${ }^{16}$ In other words, fantastical narratives were intimately related to conceptions of knowledge and to social and political power relations. But they are also, as Luise White has emphasized in her study of the widespread vampire stories across colonial Africa, a way of speaking and writing about real social, political, and environmental changes that cannot be separated from the specific contexts from which they emerge. ${ }^{17}$

White's specific attention to the formulaic elements of vampire stories in different regions and times in colonial East Africa and Central Africa showed that analytic attention to genre can produce new historical insights. Since genres are, at a basic level, "strategies of writing and speaking," they provide valuable clues for how people think about their experiences. And as Karin Barber's work on texts and genres has shown, experimentation with genre can be a useful indicator of social and political change. ${ }^{18}$ Put another way, when different ways of speaking and writing flourish, they are signaling that the social landscape is deemed to require alternative strategies of communication. For, as David Scott has recently emphasized, time and narrative are also crucial to analyses of genre. ${ }^{19}$ I want to follow Scott in moving this work on genre into the realm of historical conjuncture; into specific historical experiences with time and its renderings.

This essay foregrounds representations of the present, through the currency of news reports, as a way to illuminate how questions of time, historicity, and colonial knowledge regimes merged, mobilizing West Africans in an era that saw both an increasingly invasive form of colonial rule and anti-colonial agitation. The first section outlines the social and political context of 1930s Nigeria as well as the contours of the West African press, while the second and third analyze the writings of Tom Tinkle and Roving Hobo, respectively. While Tinkle and Hobo enabled new and various "horizons of expectation," as newspaper columnists they were primarily engaged in creative renderings of the present, temporally and spatially destabilized, but nonetheless very real and concrete. This is what I mean by bounded transcendence- the news they reported grounded them to the earth, while the idiom of flight and their ubiquity flouted the material realm. They combined an absurdist, fantastical narrative with real events, places, and people. Tinkle, in particular, responded to Europe's teleology not by ordering time in a period of change, but rather by

\footnotetext{
16 David Pratten, The Man-Leopard Murders: History and Society in Colonial Nigeria (Edinburgh: Edinburgh University Press, 2007).

${ }^{17}$ Luise White, Speaking with Vampires: Rumor and History in Colonial Africa (Berkeley: University of California Press, 2000), 206-7.

${ }^{18}$ Karin Barber emphasizes that changes to modes of address are key indicators of social and political change; "Introduction" I. B. Thomas and the First Yoruba Novel (Leiden: Brill, 2012), 48.

${ }_{19}$ David Scott, Omens of Adversity: Tragedy, Time, Memory, Justice (Durham: Duke University Press, 2014), 68-71.
} 
cultivating disorder in the present. Hobo's temporality proceeded slightly differently, and reflected the historical shift in the late 1940s toward negotiating the end of colonial rule. But the writings of both show that while the vocabularies of nationalism and pan-Africanism, as Toyin Falola has emphasized, were "politically engaged and ideologically focused" to the point of violence by the 1940 s, they also contained ambiguity and experimentation. ${ }^{20}$

I will use the term "time-space" to represent two key components that are visible through the journalists explored here: first, the term represents the particular historical time of the late 1930 s to the late 1940 s and the particular space of colonial Nigeria; second, it reflects the interrelation between these two dimensions of time and space, which Tinkle and Hobo juggle and play with in varied configurations. Their playing with time and space facilitated an array of social and political projects that help us to see key elements of what was at stake for Nigerians, and of how this changed, as they maneuvered a shifting social and political landscape. And, crucially, these conclusions are only possible if we pay close attention to the genres and modes of address these columnists employed. Their shape-shifting and zooming about mirrored their process of convening audiences on different scales, locations, and dimensions.

\section{LATE COLONIAL NIGERIAN PRINTING CULTURE}

Nigeria was changing at dramatic rates in the 1930s and again in the 1940s. Throughout most of the 1930s Nigeria suffered a prolonged economic depression, which allowed the large European firms to consolidate their monopoly over trade and ensure that few Nigerian businesses survived as large-scale importers. Migration from the provinces to the southern cities expanded exponentially: the city of Lagos is estimated to have doubled in population, from 126,000 in 1931 to between 250,000 and 350,000 by $1950 .^{21}$ These provincial migrants to the city also arrived with greater levels of Western-style education. This occurred in part because the colonial administration began to involve itself directly in the delivery of education that, until the 1920 s, had mainly been left to missions. It is estimated that between 1921 and 1937 the number of primary schools grew by 60 percent and secondary school enrolment rose eight-fold to over four thousand pupils. Literacy rates are harder to find than those of school attendance, but by 1952, an average of 8.5 percent of Nigerians over the age of seven were considered literate in roman script. Literacy rates reveal the characteristically uneven take up of Western-style education in Nigeria; they varied less across urban/rural lines than across those of ethnic group and region:

20 Toyin Falola, Colonialism and Violence in Nigeria (Bloomington: Indiana University Press, 2009), 131.

21 Quoted in Abosede A. George, Making Modern Girls: A History of Girlhood, Labor, and Social Development in Colonial Lagos (Athens: Ohio University Press, 2014), 90. 
while the country's Eastern Region and Western Region recorded literacy rates of 16 and 18 percent, respectively, the average in the Northern Region was just 2 percent (although literacy there in Arabic-script was 5.4 percent). ${ }^{22}$

This meant that the 1930s brought a new character to the educated class. On the one hand, there were the second- and third-generation graduates of a typically Christian, mission-educated, and urban background. This group, often made up of "native foreigners" and "Saro," named because they were descended from Sierra Leone re-captives, had long assumed leadership roles in their communities that included running their own newspapers. The firstgeneration graduates of the 1930s differed from this group because they were often from rural farming or small trade families that maintained ties with the provinces. These educated recruits vied for the most desired jobs in government and commercial clerkships. But expansion in government, railway, and mercantile ventures could not keep up with this ambitious new group of workers. Communal progress unions, economic associations, political parties, and labor unions appeared in ever greater numbers demanding better jobs and conditions for Nigerians, as opposed to foreigners and "native foreigners." 23

Newspapers in West Africa, which circulated fluidly between British West African colonies after the 1880 s, reflected this shifting terrain. ${ }^{24}$ In the first half of the twentieth century, editors throughout the African continent had affirmed themselves as community leaders and a contingent of "campaigning journalists" emerged. ${ }^{25}$ But two significant changes to the Nigerian press began to take shape in the 1920s and 1930s. First, the close connection between newspaper, leader, and political party began in the 1920s when the Lagos Daily News, managed and often edited by Herbert Macaulay, promoted the work of his Nigerian National Democratic Party (NNDP). Second, after the mid-1930s West African campaigning journalists began to be annexed by a more "confrontational political style centered on naming and shaming of

22 James S. Coleman, Nigeria: Background to Nationalism (Berkeley: University of California Press, 1971), 134-35. For the uneven take up of education at various times and between groups, see also Philip Zachernuk, Colonial Subjects: An African Intelligentsia and Atlantic Ideas (Charlottesville: University of Virginia Press, 2000), 50-54; 82-84.

23 Zachernuk, Colonial Subjects, 80-94.

24 For an excellent analysis of how these newspapers asserted themselves as an egalitarian outlet for civil society, yet within existing hierarchies, see Stephanie Newell, The Power to Name: A History of Anonymity in Colonial West Africa (Athens: Ohio University Press, 2013), 29-43. For overviews of press history, see Fred I. Omu, Press and Politics in Nigeria, 1880-1937 (London: Longman, 1978); Dayo Duyile, Makers of Nigerian Press: An Historical Analysis of Newspaper Development, the Pioneer Heroes, the Modern Press Barons and the New Publishers (Nigeria: Gong Communications, 1987).

${ }^{25}$ Emma Hunter and Derek Peterson, "Introduction," in Stephanie Newell, Emma Hunter, and Derek Peterson, eds., African Print Cultures (Ann Arbor: University of Michigan Press, 2016), 14-18. For the intellectual aspects of a West African cultural network see Toyin Falola, Nationalism and West African Intellectuals (Rochester: University of Rochester Press, 2001), 60-81. 
antagonists." 26 This critical voice even extended to more conservative newspapers, such as J. V. Clinton's Calabar-based Nigerian Eastern Mail. ${ }^{27}$ This more confrontational style, along with demographic, economic, political, and social shifts, spawned newspaper readerships. In two years the Nigerian Eastern Mail increased its circulation by one and a half, from two thousand in 1935 to 3,160 in 1937. Weekly circulation of newspapers across Nigeria in 1920 has been estimated at around three thousand; by 1937 the combined circulation of three dailies and nine weeklies was around forty thousand. Much of the growth in print revolved around Lagos. During these same years, twenty-two new papers appeared in Lagos alone, five of which were in the Yoruba language. $^{28}$

By far the most notorious and most vocal of this press sphere was Nnamdi Azikiwe's West African Pilot and the "Zik press" consortium that emerged after Azikiwe acquired provincial affiliates. Both columnists examined in this paper appeared in the Zik press. Tom Tinkle's "Here, There, and Yonder" appeared in the West African Pilot in its early days, when the paper was heavily invested in establishing its voice and position in the West African public sphere. Roving Hobo's "Sparks and Tiffs" appeared a decade later, in a newspaper that had initially served as an alternative (but not antagonistic) venture to Azikiwe's newspaper. Duse Mohammed Ali, a man renowned in pan-African circles for his African Times and Orient Review, which he published intermittently from London in the 1910s and 1920s and which briefly employed Marcus Garvey, founded the Comet as a weekly newspaper in 1933 after he moved to Nigeria. The newspaper survived Ali's death in 1945, when it was acquired and incorporated into the billowing consortium of the Zik press as a daily newspaper publishing from the Lagos suburb of Yaba. ${ }^{29}$ As Isabel Hofmeyr has shown in her study of the "colonial-born" Indian diaspora press in southern Africa, early twentieth-century entrepreneurial newspapers often maneuvered the difficult task of attempting to be both entrepreneurial and philanthropic. In colonial West Africa, the "Zik press" emerged as one of the first to successfully pull off this double-edged sword.

When Azikiwe returned from abroad and founded the West African Pilot in 1937, the paper immediately became known for expressing a more militant racial consciousness and for its more sensationalist rhetoric and entrepreneurial goals. With all of these hooks for popular attention in mind, the Pilot tapped

26 Newell, Power to Name, 94.

27 Pratten, Man-Leopard Murders, 178.

28 Zachernuk, Colonial Subjects, 87.

29 Ian Duffield, "The Business Activities of Duse Mohammed Ali: An Example of the Economic Dimension of Pan-Africanism, 1912-1945," Journal of the Historical Association of Nigeria 4 (1969): 571-600; Ruth Watson, "Empire Loyalism and Pan-Africanism in The African Times and Orient Review," paper presented at Print Media and the Colonial World Conference, University of Cambridge, 16-17 Apr. 2015. 
into the aspirational rhetoric of an older educated elite but, increasingly, also the large number of educated Nigerians "previously excluded or unmobilized." 30 The Pilot announcements and society pages were usually filled with information about meetings of organizations like the Goodwill Society, the Shakespeare Society, or the Railway Station Union. This was a modern newspaper and, as the paper repeatedly emphasized, a business enterprise. Its columns rehearsed the role of the newspaper in modern society just as it promoted ideas about what a "modern" Nigeria should look like.

In addition to punchy editorials and Azikiwe's feature column, "As I See It," the newspaper ran a Sports page, a Children's Corner, and a women's column called "Milady's Bower." Women's columns were a popular forum in the newspapers of the 1930s, where urban women wrote letters and debated the advice of columnists regarding how modern women should dress, run their households, and be educated. The Pilot's columns entered a discussion among daily newspapers about the value of Western-style vocational training for girls and methods of child rearing. As Saheed Aderinto has shown, the Pilot articulated a clear consumer-oriented philosophy of childhood that emphasized scientific skills and developing imagination in children, and which reflected the aspirant educated class with disposable income to purchase the newspaper. ${ }^{31}$ But Aderinto also rightly emphasizes that this was one classand gender-oriented position among many. These newspaper columns show how becoming "modern" was, as Aderinto puts it, a "selective modernity" variously debated across class and ethnic lines in Nigeria, which did not necessarily assume an easy binary between adopting "Western" customs or preserving local practices. ${ }^{32}$

If economic and ethnic associations took off in the 1930s, so, too, did literary associations. In the 1920s a group of young men, including Azikiwe before he left Nigeria to study in the United States, founded the Youngmen's Literary Association. By the mid-1930s a Literary and Debating Society and Study Circle sponsored essay writing, lectures, debates, and book reviews. ${ }^{33}$ "Our Literary Alcove" in the Pilot reflected, again, the educated component of its readership. But the book reviews that were selected also articulated the emphasis the newspaper placed on a black, pan-African racial consciousness. Book reviews included features on "The Colour Problem," "Abraham Lincoln," and even a review of Azikiwe's book, Renascent Africa, by Sylvia Pankhurst's London-based newspaper, New Times and Ethiopia News.

30 Coleman, Nigeria, 224.

31 Saheed Aderinto, "Researching Colonial Childhoods: Images and Representations of Children in Nigerian Newspaper Press, 1925-1950," History in Africa 39 (2012): 241-66, 254.

32 Saheed Aderinto, When Sex Threatened the State: Illicit Sexuality, Nationalism, and Politics in Colonial Nigeria, 1900-1958 (Urbana: University of Illinois Press, 2015), 36-40.

33 Coleman, Nigeria, 214-15. 
Finally, the more aggressive culture of the Zik press occurred within the context of the expansion of political associations and parties, as well as constitutional reforms. Complicating both of these factors was the fact that, as an amalgam of a colony and two protectorates, Nigeria had distinct regional units as well as a web of native authorities. While some elements favored increased autonomy for the small native authorities, most British administrators and Nigerian nationalists came to agree by the 1940s that some form of regional or federal structure would be best. Indeed, how quickly "Nigerianization" of government departments would occur, and how authority and autonomy would be distributed within the units of government, were much more contentious than the fact of some form of constituent structure of government. Within these confines, the growth of newspapers and the development of multiple political parties went hand in hand. The Daily Service, for example, began its life in 1938 as the organ of the Nigerian Youth Movement (NYM) and later went on to support the platform of Obafemi Awolowo's Action Group (AG). The Zik press supported the NYM in its early years, but switched its allegiance after the founding of the National Council of Nigeria and the Cameroons (NCNC) in 1944.

The debates about increased Nigerian participation in the institutions of government also involved contestations over leadership and control of space that had racial, religious, regional, ethnic, and linguistic factors feeding the competition. ${ }^{34}$ After 1941, what were referred to as "tribal" loyalties played an increasingly prominent role in social and political conflict. As an Igbo, Azikiwe had emerged as one of the first non-Yoruba Nigerians to gain prominence. His success served as a symbol of achievement that mobilized Igbo and other non-Yoruba support in contrast to the largely Yoruba-supported Action Group. This competition played out, in large part, as a "press war." This meant that by the late 1940s invoking the vocabulary of the "Renascent African" (as Tom Tinkle did in this article's opening greeting from 1938) signified more than an idea about a new man or society; it became a code for party allegiance to the NCNC and their plan for an independent Nigeria.

The West African printing culture that I have just outlined has important implications for how we can understand the Nigerian columnists I am focusing on. First, social and political transformations were intertwined. The sense of change underway at the economic, social, and political levels meant that positions stated in the press held an array of often interconnected implications. Second, and relatedly, it is crucial that the number of newspapers in Nigeria grew exponentially in the 1930s, and that by the 1940s these newspapers fiercely and regularly defended divergent social and political visions. As Luise White has emphasized, newspapers in colonial Africa did not

\footnotetext{
${ }^{34}$ Wale Adebanwi, "The City, Hegemony and Ethno-Spatial Politics: The Press and the Struggle for Lagos in Colonial Nigeria," Nationalism and Ethnic Politics 9, 4 (2004): 25-51.
} 
automatically contain the truth, but rather, "many contending versions of it" that, in the case elaborated here, Nigerians had to unpack. ${ }^{35}$ The printed word was not preordained with a more valid truth — it was also up for debate.

AN ENIGMA WRAPPED IN A RIDDLE: THE TROPE OF FLYING IN TOM TINKLE

Who was Tom Tinkle? It is not possible to tell whether the pseudonymous character of Tom Tinkle was written by one author or many. The character was most definitely male, and identified directly with the supposedly universal but in reality heavily masculinist program of Nnamdi Azikiwe's call to awaken a New Africa. Outside of these identifications, Tom Tinkle characterized himself as an "enigma," an "axiomatic problem" who could not be pinned down, literally: "Today I am here, tomorrow I am there, next tomorrow I am yonder."36 Tinkle was designed to be integrated into many different contexts, to have many voices and be in many places and thus to be able to speak to anything. Tinkle was an open program. He could speak to Englishmen because he implied that he had lived abroad. He could speak to the variety of Nigerians because he could mutate from a Christian to a Muslim. There is an element of chaos to Tinkle, yet the character is not without its traditions. Tinkle was marked by recognizable qualities appropriated from British and African textual traditions, even as the character defied any single genre or voice. ${ }^{37}$ The pseudonymous character was both recognizable and unique. This section first involves a literary analysis of the genres and voices Tom Tinkle employed to create a character who could be all things to all people and exist in all times and places. The section's second half then locates Tinkle's news reports in urban Lagos's social and political present by identifying some of the issues Tinkle's column tackled. Tinkle's flying and shape-shifting were a tool for political comment that opened up the imagination of Renascent Africans to the transformative social and political program for a New Africa.

In a West African Pilot editorial of 1 September 1938, Tom Tinkle's style was heralded as both "exemplary of literary satire, which is patterned after his prototype, 'John Bull,", as well as "salutary in exhuming covert practices which are, to all intents and purposes, inimical to the progress of this country and the crystallization of genuine and lasting inter-racial cooperation."38 The British-born model of John Bull was certainly part of Tinkle's persona. In one of his earliest columns, Tinkle declared that his watchword "is plain talk to all men, women, children and things-Government or

35 White, Speaking with Vampires, 57.

36 "Here, There, and Yonder," 25 Oct. 1939: 6.

37 This combination bears a resemblance to the incorporation of British and Indian print traditions into the Indian diaspora presses in Africa elaborated in Hofmeyr, Gandhi's Printing Press, 34-39.

38 Editorial, “Tom Tinkle," West African Pilot, 1 Sept. 1938: 4. 
non-Government, political organizations or non-political organizations, individuals or groups — straight from the shoulders." ${ }^{\text {, }}$ Like John Bull, Tinkle presented himself as honest and matter-of-fact. He was a character who drove action against exploitation with commonsense arguments presented (for the most part) in a jovial rather than combative manner.

Yet while Tinkle certainly borrowed from British archetypes, he also resembled several West African traditions. Although he did not embody any of the conventional physicalities of a West African trickster character, he certainly employed a trickster mode. At times, he admitted that he played the dunce in order to make a point. "He knew whence it began to where it ended and yet he pretends to know nothing. That's Tinkle when he plays the ignoramus." 40

Tinkle could "play" the fool, but he could also call up wisdom as an allseeing and all-knowing character. He described himself as a "diplomat" who "touch[es] a lot of matters of importance." 41 Travel narratives in African newspapers introduced new worlds and located authors in distant (and near) communities, serving as both an exercise in self-expression for authors and a way to locate and socialize particular communities. ${ }^{42}$ Tinkle could perch on a policeman's shoulder as he drove his motorcycle, or fly into a government official's office and see the memos on his desk. The closest model for Tinkle may have been an early Gold Coast press character that appeared in the Western Echo from 1885 to 1887 . According to K.A.B. Jones-Quartey, "The Owl" gained a reputation as the embodiment of the paper's editor, who seemed to have an uncanny ability to ferret out official secrets and pass them on with equally mystifying speed to his readers. The Owl hovered "aloft on wing above Elysium the "bird of wisdom" espied the abode of Tutivillus. Shall I enter an appearance there in broad day light?"43 The quality of wisdom ascribed to Owl, achieved through flight and observation, is the closest available model to Tom Tinkle. And if this West African character was Tinkle's precursor, Tom Tinkle's travel, flight, and preference for pockets foreshadow Langston Hughes's character Jesse B. Semple, better known as "Simple," introduced in a column titled "Here to Yonder" in the Chicago Defender in $1943 .{ }^{44}$

39 "Here, There, and Yonder," 29 July 1938: 7.

40 Ibid., 10 Sept. 1938: 7.

41 Ibid.

42 Rebecca Jones, "The Sociability of Print: 1920s and 30s Lagos Newspaper Travel Writing," in Stephanie Newell, Emma Hunter, and Derek Peterson, eds., African Print Cultures (Ann Arbor: University of Michigan Press, 2016), 102-24; Janet Remington, "Solomon Plaatje's Decade of Creative Mobility, 1912-1922: The Politics of Travel and Writing in and beyond South Africa," Journal of Southern African Studies 39, 2 (2013): 425-46.

43 Quoted in K.A.B. Jones-Quartey, History, Politics and Early Press in Ghana: The Fictions and the Facts (Accra/Tema: Ghana Publishing Corporation, 1975), 86-87.

44 Stephanie Bosch Santana, "From Harlem To Lusaka: Mapping the Township Tale," paper presented at African Print Cultures Workshop, Magaliesburg, South Africa, 20-23 June 2016. Whether 
The substance and character of Tinkle's audience (and his subjects for critique) marked the column with certain qualities familiar in African print practices; namely, with the tendency to embrace "a mixture of textual modes and kinds of audiences." 45 The genres contained in "Here, There, and Yonder" could range from serialized short story telling, to political satire and comment, to whole columns of proverbs and parables, to statistics and reports, or reprinted letters from Tinkle's readers. When Tinkle announced himself "on the move" this sometimes coincided not with comment on the local administrators or the latest news, but rather the incorporation of parables and proverbs, which he declared was "the stuff to give 'em when you feel [sic] to be enigmatically enigmatic." 46 This switching of genres was a common practice with important implications for locating readers in time and space. In the 1920s Yoruba-language newspaper Akede $E k o$, I. B. Thomas produced the serialized story of "Segilola," which sometimes disrupted its narrative to reprint and respond to letters from readers. By engaging with correspondents as well as by including specific dates within the storyline, this fictional narrative, as Karin Barber emphasizes, was also "hooked into real time." 47 Tinkle's column was filled with references to popular places and well-known individuals whose "pocket" he would drop into next. While he could be found dancing, prancing, waltzing, jumping, and flying in his daily "walkabouts," his critiques were always made from a fixed location.

By cultivating a wide audience and subject matter, Tinkle purposefully set about constructing a character that could be relevant to many different contexts in Nigeria. Once a week he declared his day for "sermonizing" on religious matters, typically applying Christian scripture and traditions. But since Tinkle had "many readers of different religious beliefs," he sometimes "decided to put aside his convertible collar and change his coat and hat for the Muslim's gown and turban. That's Tinkle as a Muslim." By shifting from a Christian to a Muslim, Tinkle could address the predominantly Muslim northern region of Nigeria as well as readers in the South. He could quote from the Quran and implore all "Renascent Africans [to] believe in God, [and] hold yourselves as one man," then just as easily "put aside his turban and gown" to criticize "Mr. English Government Printer." 48

\footnotetext{
or not Hughes was inspired by the character of Tom Tinkle requires further research. Although Hughes and Azikiwe knew each other, I have found no concrete evidence in the Langston Hughes Papers at the Yale Beinecke Rare Book and Manuscript Collection to suggest that Hughes read the West African Pilot at the time. On Hughes and Azikiwe, see Obiwu, "The PanAfrican Brotherhood of Langston Hughes and Nnamdi Azikiwe," Dialectical Anthropology 31, 1/3 (2007): 143-65.

${ }_{45}$ Karin Barber, The Anthropology of Texts, Persons and Publics: Oral and Written Culture in Africa and Beyond (Cambridge: Cambridge University Press, 2007), 171.

46 "Here, There, and Yonder," 14 Jan. 1939: 9.

47 Barber, "Introduction," 5-6.

48 "Here, There, and Yonder," 22 Aug. 1938, 7.
} 
Tinkle's principal allegiance to Renascent Africans and, specifically, West Africans, was complicated by overlapping claims. In his early columns, Tinkle especially emphasized a blindness to race. Yet while Tinkle sent "greetings to the public, White and Black," he declared his primary aim was "to do good for his race and mankind and see that the New Africa is built on solid foundation." "49 Tinkle's shifting constitution of a "citizenry" resembled the mode of address applied by early twentieth-century Zulu author Magema Fuze. The "simultaneous rootedness and billowing expansiveness" of Fuze's public, as Karin Barber has shown, enabled the "conven[ing] of publics on several different scales at once." 50 This public was "simultaneously personal and impersonal, local and indefinitely extensive."51 Just like Fuze, Tinkle applied a mode of "wavering address" to both "White and Black," Muslims and Christians. He moved between Nigeria, West Africa, Paris, and London. Tinkle's bounded transcendence, then, worked on at least two levels: It was geographic, through his transcendent flight and his landing at specific locations, and it was also social, through his expansive and rooted personal identity and audience.

Ultimately, Tinkle was a complex amalgam of forms and styles that made him highly transient and preternatural. Crucially, while Tinkle convened multiple publics he also fully existed within and simultaneously transcended the material realm of these publics. That is, Tinkle's audience is shifting and moving, but so is Tinkle. He is a Muslim and then a Christian. He has been abroad but is now in Africa. He flies around to different places and, as in his adage that "to Tinkle London is like West Africa," all places are not, actually, so different at all. Tinkle not only adopts layered scales of address simultaneously, but he exists in multiple skins. He exists at once in all places and times, he is ubiquitous; he is a "human being" who can err but he is also an "enigma," a being that can be more than one thing at the same time or could be multiple versions of the same thing at the same time. While earlier Nigerian editors used their physical travel to acquire new readerships and transmit news, Tinkle's multi-sited, multi-form movements served to parallel the kind of audience he convened in a highly inventive form.

Tinkle's "ubiquity," his ability to exist within and outside the conventional logic of time and space, I want to suggest, was a strategy for marking out a new terrain in late 1930s Nigeria. This was, Tinkle lamented, an "uncertain age," where "everything is change." 52 The columnist's mutations paralleled a changing and reforming audience. If Tinkle's mobility allowed him to narrate the news; to flex his international credentials and prove his authority as a man

49 Ibid., 29 July 1938: 7.

50 Barber, Anthropology of Texts, 155.

51 For the layered scales of pan-African address in the Nigerian press, see also Barber, "Introduction," 47.

52 "Here, There, and Yonder," 5 Dec. 1938: 7. 
"in the know"; to interpolate ordinary news with political comment; and to overcome the human and technological limitations of the day in order to exist in all places and all times, his mobility also signaled his print citizenship and, by extension, his social and political allegiance. The trope of flying was an important allusion to the West African Pilot. When Tinkle performed his warnings to colonial administrators or errant Africans as an "expert airman" who "means to pilot," he affiliated the writer with the paper. Both author and medium gained greater credibility as the voice of the common man that would steer a true course for "the people." This section shows how the trope of flying allowed Tinkle to navigate three interrelated aspects of a modernizing Nigeria: social, political, and historical. Tinkle's mobility gave voice to a widely shifting time-space across gender, class, regional, and ethnic experiences, even as his own arguments identified a more specific transitional program.

Nnamdi Azikiwe first elaborated his five-stage plan for African transformation in 1933 in the first edition of his book Renascent Africa. After its second edition in 1937, the concept gained wider currency and was applied, interpreted, and altered along the way by a variety of individuals. ${ }^{53}$ Importantly, the "New Africa" that Azikiwe called forth in his book was not a geographic remapping or reordering but instead a "psycho-social" transformation. The five pillars of this staged plan required: spiritual balance, social regeneration, economic determinism, mental emancipation, and finally, a national risorgimento. This final stage of "political status" would, Azikiwe argued, inevitably arise from the spiritual transformation of the individual and the transition to a new social order. ${ }^{54}$ It is this transitional aspect to Azikiwe's Renascent African concept that, I want to argue, helps to explain the political use that travel and mobility played in the columns of Roving Hobo and Tom Tinkle.

When Tinkle applied the vocabulary of "Renascent Africa" or "New Africa" in his column he did so with the substantive confidence that his readers understood the meaning behind these terms. In its early years the West African Pilot offered a free copy of Azikiwe's book as an incentive to subscribe to the paper. Azikiwe's regular column, "Inside Stuff," sometimes serialized sections of the book directly in the paper as well. His column denounced those without "spiritual balance," and letters called upon fellow readers to "break away from tradition" in order to develop Africans as "a race of men who know that Love governs the Universe." 55

This particular reader's discussion of love was about wider social care, but love was very much on the minds of a changing Lagos. When Tinkle "dropped" into the "handbags of Lagos society ladies, white as well as black," he reflected

53 George, Making Modern Girls, 211-12.

54 Azikiwe, Renascent Africa, 8-10.

55 S. D. Opuyo, "Public Opinion," West African Pilot, 16 Sept. 1938: 2. 
upon the need for "every male and female" to "go a-shopping until he or she finds the right thing he requires." Tinkle also tapped into the anxieties of these society ladies, who focused their activity in particular on the dangers of the street for young girls in urbanizing Lagos, when he chastised men who "waste strength on hitting and ill-treating" women or "forcing her out into the street." ${ }^{.6}$ Anxiety about women on the street related to debates about sex, marriage, divorce, and the changing gender roles that were emerging from the legalization of divorce (which was seen to undermine male authority). When Tinkle urged his readers not to let "divorce suits make you shy to go a wooing," he affirmed the Pilot's position that talking about sex and divorce, rather than silencing them or linking divorce with prostitution, as the Daily Service would later do in the early 1940s, were fundamental to discerning how Nigerians would modernize in relation to Western laws and customs. Not being "afraid" of divorce, but also not embracing it, was one example of the "selective modernity" that distinguished the Pilot from other nationalist or conservative opinions in Nigeria. ${ }^{57}$

Azikiwe's Renascent Africa was neither the first nor the sole harbinger of a changing society. Eyo Ita, who wrote for the Pilot in the 1940s and, just like Azikiwe, was educated in the United States, produced numerous pamphlets between 1934-1938 summoning the force of the youth of the country: "This is the day of Nigerian Youth. It must build a new social order... Mother Africa calls us to the battle front. ${ }^{, 58}$ During these same years the Lagos Youth Movement evolved into the Nigerian Youth Movement (NYM), establishing branches throughout Nigeria between 1936-1938 that were sometimes built on the foundation of local ethnic unions or branches of Ladipo Solanke's London-based West African Students Union. ${ }^{59}$ While NYM members were generally younger than the previous generation of "foreign-born," nationalist leaders (Herbert Macaulay was sixty when he founded his Democratic party in 1923), it self-consciously marked itself as being "young in mind." ${ }^{.60}$ They represented a new way of thinking.

In 1938 the NYM contested and won the Lagos Town Council elections, unseating Macaulay's dominant National Democratic party and, in theory, auguring a more representative "Nigerianization" of politics. That same year, in a move which Azikiwe evidently did not appreciate given the recent

\footnotetext{
56 "Here, There, and Yonder," 20 May 1939: 7; 1 May 1939: 7. Abosede George shows how the salvationist approach of Lagos society ladies often conflated street hawking, street-walking, and prostitution in their anxieties about sexual deviance in urbanizing Lagos; Making Modern Girls, ch. 4 .

${ }^{57}$ Aderinto, When Sex Threatened the State, 143-48.

${ }^{58}$ Quoted in Coleman, Nigeria, 219.

${ }^{59}$ For WASU's influence in Nigerian politics see Coleman, Nigeria, 204-10. See also Hakim Adi, West Africans in Britain: Nationalism, Pan-Africanism, and Communism (London: Lawrence and Wishart, 1998).

${ }^{60}$ Zachernuk, Colonial Subjects, 108-10.
} 
launch of the West African Pilot, the NYM established the Daily Service as their organ, edited by Ernest Ikoli. The year 1938, when Tinkle first appeared, thus marked a significant shift in Nigerian politics that, importantly, was never dominated by one individual or way of thinking. Azikiwe remained in support of the NYM between 1938 and 1941, the same years that "Here, There, and Yonder" ran in the West African Pilot. Whether or not this chronology directly correlated, it is at least symbolically significant that the West African Pilot lost its most direct "everyman" voice in the midst of an acrimonious political divorce that showed the first signs of ethnic politics in Nigeria. ${ }^{61}$

As the Youth Movement spread outward from Lagos migration from the provinces to the city were essential to Lagos's development. Ethnic associations and "tribal" unions, and the dances and events they hosted, increasingly served to define social space in Lagos, even as they fulfilled their primary aim of facilitating contact with the provinces and with hometown community development. We can see Tinkle's regular flights around the provinces, and letters from readers imploring Tinkle to visit them, as one strategy for facilitating urban and provincial contact in this context. In March 1939, Tinkle described his visit to Efon Alaye, which occurred via "an unknown friend [who] has sent me a Newspaper cutting." 62 Briefly revealing his travels to be metaphorical rather than real, Tinkle also displayed his method. He gathered news not by actually traveling to the places he named but through a community of readers who wrote back. Although the West African Pilot was a Lagos paper, it claimed circulation throughout Nigeria. Letters denouncing Tinkle for failing to regularly visit Kano in the north, followed by Tinkle's apologies and promises to return soon, affirmed the dominance of Lagos and the south even as the Pilot claimed to aspire to a unified Nigerian politics and Nigeriawide circulation. When Tinkle aimed to land on the nursing home roof where "Mr. U. Duakpemi" of Apapa was "laid up" sick, these names and places punctuated by Tinkle's flights served as one imaginative way to connect Nigerians from different regions. ${ }^{63}$ But this imbalance, between claiming an inclusive community while in practice attending to more narrow regional or group issues, became a key feature of party politics and the press in the later 1940 s. $^{64}$

If Tinkle's mobility connected a diverse and disparate community, the most prominent function of his flight was to cunningly report news about local administrators and businessmen. His mobility mirrored the social transformations underway, but it also functioned as a tool to expose colonial maladministration by the state and by the large firms that dominated economic trade.

61 Coleman, Nigeria, 227.

62 "Here, There, and Yonder," 31 Mar. 1939: 7.

63 Ibid., 15 Dec. 1938: 7.

64 Aderinto, When Sex Threatened the State, 43. 
The emerging politics of nationalism in 1930s Nigeria was tied to anticorruption and displayed strong anti-monopoly criticism of the large European commercial firms, especially the United Africa Company. ${ }^{65}$ While claims to know the workings of imperial power were common in West African editorials and articles, Tinkle's transmutations and flights articulated a palpable presence in areas his readers were typically excluded from.

Rather than print a notification that a colonial official was leaving on holiday, Tinkle entered his monoplane "full of thought" on 2 March 1939, and flew to Khartoum "from where he will see the Hon. G. C. Whiteley off to England on a well-earned holiday." ${ }^{\text {"66 }}$ By flying to Khartoum, Tinkle demonstrated that Nigeria's border was no barrier to him. And by narrating the news through flight, Tinkle could interpolate political comment into what would, in standard news form, be dry reporting. Ushering in the new year on 3 January 1939, Tinkle announced: "He will begin tomorrow by flying on the roof of the "Nigerian Daily Times." He will then go to the Nigerian Railway Workshops. There is quite a lot to be done in these areas. Tinkle wonders many a time when he does visit the desks of some of these heads of departments, how some men could be so discourteous as to leave petitions upon petitions unanswered.... The firms will come under serious scrutiny, especially the United Africa Company ... he will then take his monoplane and fly into the Provinces." 67 Tinkle's criticism of "especially the United Africa Company" and focus on the civil service aligned him with the specific cause of the "youth" era as well the overall "spirit" and attitude of this secular reform generation who "spoke the language of Pan-Africanism but calculated things closer to home." 68

In July and August 1938 Tinkle focused most of his energy in defense of Nigerian civil servants, whose jobs were believed to be under threat from "labour saving machines" that the Customs Clerk planned to purchase. Editorials in the Pilot argued that, while machines were "inevitable in our socioeconomic evolution," the employees that were cut should be Europeans, not Africans. ${ }^{69}$ While these concerns criticized specific aspects of using calculating machines, Tinkle focused on the politics of the act. "A Government should help to provide jobs and not to throw poor people out of jobs." Tinkle threatened to activate his metropolitan networks if the Comptroller of Customs did not reverse his plan: "He will be compelled to refer matters to Dr Harold Moody, 164 Queen's Road, Peckham, London, for kind consideration of the Home Office."

65 Pratten, Man-Leopard Murders, 173-77; Zachernuk, Colonial Subjects, 108-10.

66 "Here, There, and Yonder," 2 Mar. 1939: 7.

67 Ibid., 3 Jan. 1939: 7.

68 Zachernuk, Colonial Subjects, 123.

69 Editorial, "Comptometer Machines," West African Pilot, 17 Aug. 1938: 4; L. N. Okogwu, "Public Opinion: Customs Calculating Machine," West African Pilot, 18 Aug. 1938: 6. 
Moody was a Jamaican-born doctor who resettled in London and, in 1931, set up the League of Coloured Peoples (LCP). It served as a pivotal destination for petitions and news from both Caribbean and African colonies, often in close cooperation with Nigeria-born Ladipo Solanke's WASU (West African Students Union). ${ }^{70}$ Printing Moody's direct address in "Here, There, and Yonder" served three purposes: it proved that the threat could be completed; it enhanced Tinkle's credentials as an agitator by proving he could circumvent local authority through a direct line to the metropolis; and it alluded to the real author's worldliness as someone who had returned to Africa from abroad. From the character's earliest appearance, there was an international edge to his mobility that gave credence to his authority.

Tinkle's threatened international travel pressed the particular concern with labor and the value of work, and its connection to colonial governance. The pay, hours, and working conditions of civil servants were a regular feature of the news Tinkle printed. "Here, There, and Yonder" printed letters from provinces to "the son of King Tom" complaining about the service at postal stations, and Tinkle's regular flights to understaffed postal outlets around the provinces echoed specific queries by African unofficial members in the Legislative Council about the lack of African staff in their own districts. The Nigerian Railway, as the largest employer of waged labor throughout the colonial period, came under particular scrutiny. ${ }^{71}$ In December 1938, the colonial government announced a new pay scheme for daily and hourly paid clerks of the Railway, which would come into effect in January 1939 and would see all daily and hourly clerks paid on a salary scale with annual increments to be determined "strictly on merit and at the discretion of the ... Heads of Department."72 This information was initially printed in Zik's "Inside Stuff" column, which also reprinted the transcript of the Legislative Council throughout the month of December.

In January 1939, Tinkle brought his mobility to bear on the issue. Using his airborne status to gather knowledge, Tinkle announced that there were 1,500 men in the Labour Section of the Railway, which he had counted while he watched them "like ants all going to the Loco Department" (the wordplay here with "loco" is also typical of Tinkle's style). After observing these ants, Tinkle announced that he would henceforth be their advocate: it was "impossible for the General Manager to come into direct touch with all sections" and so Tinkle "decided, being ubiquitous, to act as a guide to the good old General Manager of this department."73

\footnotetext{
70 Adi, West Africans; Marc Matera, Black London: The Imperial Metropolis and Decolonisation in the Twentieth Century (Oakland: University of California Press, 2015).

71 Aderinto, When Sex Threatened the State, 28.

72 Zik, "Inside Stuff: Interpellations (9)," West African Pilot, 16 Dec. 1938: 4.

73 "Here, There, and Yonder," 5 Jan. 1939: 9.
} 
Over the next five months, Tinkle regularly printed statistics of wages and staffing of Railway employees. He also challenged the administration's pay scheme directly. "For a department like the Nigerian Railway with its teeming thousands of workers, Tinkle submits that this system for increments cannot work well.... It will be impossible in some instances for the boss to get in touch with some men so as to be able to rate their capacity for work.",74 Tinkle, on the other hand, could see and know all. His levity thus gave him knowledge literally above and beyond the state. His flight allowed him to challenge the political authority of Legislative Council questions, while also presenting himself as a guide and a help to government officials.

Tinkle relied on official reports and Legislative Council debates for some of his information, and he broadly supported the ascension of Renascent Africans to political control, yet he could just as quickly turn and declare that he did not believe in Legislative Councils. ${ }^{75}$ These were, he stated, places where an official majority and the governor held real power and where unofficial African members" "elocutory organs go flop." Africans in this system of official politics failed to articulate themselves. Their politics was ineffectual.

This was the "problem" with Tinkle. He was forthright but also ambivalent. The character claimed to "shoot straight from the hip," but usually circled around the key issues without stating them clearly. In 1938 another pseudonymous author from the Daily Service, "Mr. I. Wash," derided Tinkle for being "unintelligible." 76 Yet if this was the problem, I want to argue that it was also the solution. Tinkle was an enigma that made his readers think. "The most woeful aspect of the system of education," the Pilot declared in an editorial in 1939, was that schools were places "where pen-pushing automata are manufactured." Youth were churned out "to be a kind of gadget" at commercial or civil service desks. ${ }^{77}$ Tom Tinkle's circuitous character was a sort of salve to this colonial education system. It was impossible to read the column mechanically; social and political knowledge was required to navigate Tinkle's allusions, but so was critical thinking.

On 19 August 1938, Tinkle declared that he "intends to grow multitudinous hands and so cultivate multifarious colours" and "develop multidimensional brains." While he often flew through the air in a man-made vehicle like a Zeppelin or an airplane, he also had the ability to achieve flight through metamorphosis. But the transformation Tinkle desired in this instance was also for a discrete purpose, and so this splitting tactic became more specific. "One or two non-Africans have so annoyed good old Tinkle that he intends early next week to divide himself into multitudinous bits of small

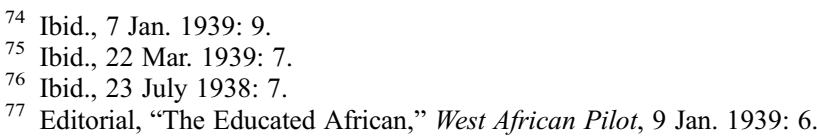


flying insects numbering thousands, biting and stinging enemies of the Renascent African. He will most likely turn himself into mosquitoes. He will likely visit the cemetery. He will perpetrate this deed on Wednesday night at about 11 pm." Tinkle's attention to date and time alluded to his ultimate purpose, which was that through his transmutation he would defy history's boundaries. "The Club of the Dead is no barrier to Tinkle as a mosquito for he associates freely with deadman [sic]." This warning was issued "with particular reference to non-Africans who know that they have been wicked to ... [the] Sons of Africa." 78

Tinkle's mobility, then, gave him the ability to transcend time- - both historical time and the time required to traverse great physical distances; and space - as a mosquito he was small enough to fit in coffins and manifold enough to bite and sting in multiple places. Tinkle's transitory dexterity thus conferred on him the ability to "land" in real and imagined time-spaces. Announcing the new year on 3 January 1939, Tinkle "arrives on the invisible and mysterious roof of the year 1939. He looks ahead, around and about and he is perplexed at the ways of the civilized world."79 The historicist time of the "civilized world" was confounding, illogical. Tinkle therefore rendered the rules of time as past-present-future ineffectual by entering (not traveling back to) the past in order to seek vengeance and restore dignity. The enemies of a rehabilitated, Renascent Africa were the non-Africans now peacefully slumbering in the "Club of the Dead."

The world of civilization and modernity in Tinkle's conjuncture was, as in Gary Wilder's idiom, "untimely"; a state where "conventional distinctions between past, present, and future no longer obtain, when tenses blur and times ... interpenetrate." Righting injustice required an untimely act. It also, crucially, required "multidimensional brains" that could think through this disjointed confusion. Writing on the cusp of World War II, Tinkle signals one of the many colonial thinkers attending to "the problem of freedom and the politics of time." ${ }^{\prime \prime}$ Through his travels, Tinkle steered his readers through the confusing terrain of colonial administration and the mortally impenetrable veil of European-dominated history which seemed to exclude Africans from its sarcophagi. In Tinkle's time-space the past and the future harbored unknown elements, but neither were a barrier that could not be overcome. Time and space were unsettled and Tinkle's audience could think in new ways about the present.

A LEAP IN TIME: ROVING HOBO’S “SPARKS AND TIFFS,” JULY 1949

I now want to make a leap in time with you from the late 1930 s to the late 1940s, passing over, along the way, events such as the West African press

\footnotetext{
78 "Here, There, and Yonder," 19 Aug. 1938: 7.

79 Ibid., 3 Jan. 1939: 7.

80 Wilder, Freedom Time, 37, 39.
} 
tour to England in 1943 where editors, including Azikiwe, pushed for selfgovernment in their "Atlantic Charter and British West Africa," past a general strike in 1945 that mobilized the expansion of trade unions as a militant force in Nigeria, and past a new constitution in $1946 .{ }^{81} \mathrm{I}$ am working here with incomplete bound volumes of a newspaper held in its fullest, but still fragmentary form, in the National Archives of Nigeria. ${ }^{82}$ From these crumbling volumes, it is impossible to tell when this particular column began or ended. I focus, therefore, on a few months in the summer of 1949. This limited sample nevertheless shows how another pseudonymous columnist played with time, location, and travel by applying modes of address and fantastical mobility. This rendering of the present, through international mobility, fashioned an unusual time-space out of uniform, homogenized wireless news reports.

Roving Hobo's column in the Comet was normally a provocative comment column called "Sparks and Tiffs," which appeared on the top right corner of the third page of the daily newspaper next to the "Readers Platform" and "Provincial News" columns. Like Tinkle, Hobo employed the third person, but unlike Tinkle he never referred to a singular gender. Hobo's column also began with a greeting and invitation followed by pointed opinion, usually on local events, notable persons, or political aspirations. The comments often related directly to the paper's major content piece, which was always positioned on the adjacent page, and usually comprised an article by a well-known international author.

In the summer of 1949 Roving Hobo's column fully embraced its pseudonym. The column became a highly idiosyncratic and composite genre whereby both the author and the style of the column underwent a shape-shifting transformation, roaming the globe to experience the latest noteworthy events. On 3 July 1949, Hobo sought to cheer his readers from the wet and rainy weather by gathering the latest news "from all Reuters stations during my globe-trotting." To all appearances, Hobo's column became a string of Reuters dispatches with GENEVA, WASHINGTON, DALAT, PERTH, and LONDON-sometimes stamped just like a Reuters dispatch with the date beside it - announcing each new paragraph. However, these were not presented by Hobo as news items from disparate locations collected together at a desk in Yaba and dispensed to Nigerians who read them, seated over their coffee at the breakfast table. Rather, both Hobo and his readers enter each space. "Here we

81 During the general strike in 1945, both the West African Pilot and the Comet were temporarily shut down by the colonial administration. Penny Von Eschen, Race against Empire: Black Americans and Anti-Colonialism (Ithaca: Cornell University Press, 1997), 56.

82 For important comment on the state of the National Archives newspaper collection, see Aderinto, "Children," 263. 
are in London," Hobo declares, before transitioning from their own narrative voice into the Reuters dispatch. ${ }^{83}$

Like Tom Tinkle, Hobo claimed superhuman powers when it came to transcending time and space: "You know that being capable of being everywhere and at the same time Hobo can equally discuss local problems. ${ }^{84}$ Hobo's physical movement endowed a cognitive capacity to comment upon all places and problems. The column could begin with "my tit bits" from PARIS, LONDON, BRUSSELS, CAIRO, before applying their "axe" to local issues such as the new Nigerian bank bill. Nationalization and African-owned business was a key theme in the Zik press. This particular bank bill claimed to curb fraud in Nigerian banking - a problem which the Comet had already reported was exaggerated to portray Nigerians negatively - but Hobo argued the bill was actually designed to discourage African banking business and ensure foreign control. ${ }^{85}$

The omnipresence of the character was, therefore, multi-local. In one day, Hobo could observe Sir Stafford Cripps in the Houses of Parliament as he delivered the Exchequer's speech on Britain's gold and silver crisis, and then leave London and land in Durban, South Africa, to witness an African bus boycott "on the same day, July 6 , at $4: 15$ pm." Note the precision in citing the date and exact time. Hobo's location could be swift and fleeting. It could move at supernatural speeds. But it was not volatile or vague. Through travel the abstract, pseudonymous "Roving Hobo" gained concreteness.

Ultimately, Hobo's foray into creative international news reporting served the evolving pan-African project of the late 1940s. By the end of the decade, pan-Africanism had blossomed significantly thanks to the solidarity facilitated by African and African diaspora experiences during World War II; the meeting of leaders at the world trade union congresses and the Manchester Pan-African Congress in 1945; widespread diaspora support for organized disturbances like the 1945 General Strike in Nigeria; and collaborative resistance against the Union of South Africa's attempts to annex South West Africa. The Pan-African movement also benefited from the celebrity and comparatively greater resources of African Americans who articulated their own national problems within a shared struggle against racism and colonialism. ${ }^{86}$ But these developments also involved unprecedented participation from Africans, as well as diaspora leaders. This 1940s Pan-African project was expressed not only through

${ }^{83}$ Roving Hobo, "Sparks and Tiffs," Comet, 3 July 1949: 3 (my emphasis).

84 "Sparks and Tiffs," 7 July 1949: 3.

85 "Nigeria in 1947 Full of Corruption and Crime, Says Review Cartoon," Comet, 3 Jan. 1948: 1.

${ }^{86}$ Carol Anderson, Eyes off the Prize: The United Nations and the African American Struggle for Human Rights, 1944-1955 (Cambridge: Cambridge University Press, 2003); Gerald Horne, Black and Red: W.E.B. Du Bois and the Afro-American Response to the Cold War, 1944-1963 (Albany: SUNY Press, 1986); Brenda Gayle Plummer, Rising Wind: Black Americans and US Foreign Affairs, 1935-1960 (Chapel Hill: University of North Carolina Press, 1996); Thomas Borstelmann, The Cold War and the Color Line: American Race Relations in the Global Arena (Cambridge: Harvard University Press, 2001). 
the pages of African and African diaspora newspapers: it came into being by way of networks of journalists and editors and the sharing of print. ${ }^{87}$

This networked black press sphere also facilitated Hobo's "globe-trotting" persona. Hobo's column nestled in the Comet alongside articles from African American political activists W. A. Hunton (secretary of the New York-based Council on African Affairs), W.E.B. Du Bois, and world famous singer, actor, and Council on African Affairs chairman Paul Robeson. As "Sparks and Tiffs" became increasingly worldly, the column incorporated these items into its expeditionary narrative as well as the Reuters dispatches. In particular, Hobo's "globe-trotting" seems to have been inspired by the April 1949 World Peace Congress in Paris. This was a Cominform-sponsored gathering, held simultaneously in Paris and in Prague (for those who were denied entry to France), which solidified Moscow's oversight of a wider communist peace movement. The meeting passed resolutions condemning NATO, opposing rearmament of Germany and Japan, and calling for the prohibition of nuclear weapons. $^{88}$ Delegates speeches, including those from African participants quoted by Roving Hobo, spoke Stalin's language of a "new threat of war" posed by imperialism. Importantly, the conference is perhaps best known for its two star African American participants. While W.E.B. Du Bois served as co-chair of the gathering, Paul Robeson's speech became the spark for widespread anti-communist vitriol in the United States against both men when Robeson was deliberately misquoted as saying that African Americans would never fight against the Soviet Union. ${ }^{89}$

Roving Hobo's column referenced and expanded upon portions of speeches, articles, and news from the Peace Congress that appear elsewhere in the same or subsequent editions of the Comet. On 5 July 1949, the paper reprinted a report by W.E.B. Du Bois on the "Coloured World in Peace Congress," in which Du Bois positioned the Peace Congress in Paris as the most important international conference for the colored world to date, outstripping the Races Congress of 1911 and the inaugural meetings of the League of Nations and the United Nations. This event was, in other words, positioned within the history of internationalism and the progress of this history into new territory. Du Bois argued that the meeting in Paris was, in the diversity and determination of its delegates, the "most impressive mass demonstration I ever dreamed of."

More than this, what was important for Du Bois was that, unlike the previous attempts at international conferences, "the coloured world was present,

87 Von Eschen, Race against Empire; Leslie James, George Padmore and Decolonisation from Below: Pan-Africanism, the Cold War, and the End of Empire (Basingstoke: Palgrave Macmillan, 2015), 69-95.

88 R. Craig Nation, Black Earth, Red Star: A History of Soviet Security Policy, 1917-1991 (Ithaca: Cornell University Press, 1992), 196.

${ }^{89}$ Horne, Black and Red, 122; Anderson, Eyes off the Prize, 161. 
not simply on sufferance; not with the palling Anglo-Saxon condescension; but as members of a world movement in full right and with full participation." 90 Not only were eighteen representatives present from French Africa, but Du Bois reported that "at two sessions black men presided" and a black African was elected vice-chairman of the World Committee. Du Bois's emphasis on participation, I want to suggest, served as the impulse behind Hobo's rhetorical adventures. The conference was portrayed by Du Bois and Hobo as a world historical event. Hobo's travel and ubiquity allowed him/her to think about Nigerian legislation as well as to contemplate the significance of an international gathering which, according to Hobo, "declare[d] the determination of the common man." 91 In the same way that Manu Goswami describes Benoy Kumar Sarkar's sociological work of the 1910s and 1920s, Hobo "sought to conceive the present in a manner that enabled the possibility of participating in history." 92

What explains Hobo's rhetorical style and its emphasis on participation? I want to suggest at least three reasons for it. First, it signaled the change in the relationship between Nigerian nationalism and black diaspora allies during and after World War II. While diaspora leaders and their metropolitan connections proved vital for Nigerian nationalists, the relationship was much more reciprocal than it had been even a decade previous. After Azikiwe deftly propagandized a rumored attempt upon his life during the General Strike of 1945, he became a well-known figure in his own right across the Caribbean, the United States, and Britain. Nigerian students and professionals living or visiting Britain intensified contacts with British members of parliament and academics. Nigerians in the United States also expanded what Philip Zachernuk has characterized as their "ambassadorial" role, publishing several books and building connections with a range of American groups. Mbonu Ojike's pronouncement in 1947 that "black Americans were Americans whose slogan should be: 'Back up Africa,' rather than ... 'Back to Africa"' is indicative of a change in the tone and indeed material power Nigerian political nationalists now displayed. ${ }^{93}$ In this context, the style and mode of address in Hobo's reporting from Paris affirmed an alliance of distinctive equals between Nigerians and diaspora advocates. By transporting Comet readers to the Peace Congress and supplementing the reprinted articles by Du Bois and Robeson with Hobo's own roaming reporting, Hobo's column signaled that this equation of equal participation could occur through translation rather than simply repetition or direct reprinting.

\footnotetext{
90 W.E.B. Du Bois, “Coloured World in Peace Congress," Comet, 5 July 1949: 2.

91 "Sparks and Tiffs," 5 July 1949: 3.

92 Goswami, "Imaginary Futures," 1468.

93 Quoted in Zachernuk, Colonial Subjects, 101.
} 
Second, Hobo's international mutation also occurred just as Cecil King's Mirror Group of newspapers sought to consolidate its presence in West Africa. In 1947 the Mirror Group acquired control over the Lagos Daily Times, previously owned by the Liverpool-based West African Newspapers Limited, as well as the magazines West Africa and West African Review. With the encouragement of the Colonial Office, in 1949 the Group expanded its reach by purchasing the Daily Graphic in the Gold Coast. ${ }^{94}$ The Zik press vocally opposed the incursion in 1947 and maintained a steady campaign against the Mirror Group in 1949. On the page opposite Hobo's column of 12 July, for example, an editorial complained that the Nigeria Daily Times's tendency to print negative news was evidence of "the master's voice dictating the tune." The "master" was identified directly as the paper's "London fountain, the 'Daily Mirror.",95 In September 1949, Hobo himself weighed in, advising all readers to "boycott foreign newspapers." 96 Hobo's creative international news reporting, therefore, may have been intended as a demonstration of what the African-owned newspaper offered its readers: a different kind of voice.

Third, Hobo's style facilitated ongoing historical debates about empire, power, and identity. Scholars of European colonial history now generally work from the premise that colonial rule, as both "a political structure and a condition of being," relied upon acquiring and articulating regimes of knowledge which were used "to reveal the state's command of the techniques and resources to set things right." 97 One of the most important of these regimes was historical knowledge. Thus, West African intellectuals in the late nineteenth century began to fill a perceived void by publishing a spate of Yoruba histories. ${ }^{98}$ "Homegrown historians" across Africa in the early twentieth century wrote histories as "manuals for their political communities." 99 Under the British Raj, nineteenth-century Indian liberals produced statistical and empirically dense studies as a form of "counter preaching" against European historicism's "moralised, relatively static and evolutionary sense of the past." ${ }^{\prime 100}$ Indeed, in India

94 Leslie James, "Playing the Russian Game," Journal of Imperial and Commonwealth History 43, 3 (2015): 509-34; John Chick, "Cecil King, the Press, and Politics in West Africa," Journal of Modern African Studies 34, 3 (1996): 375-93.

95 Editorial, "Daily Times New Policy," Comet, 12 July 1949: 2.

96 "Sparks and Tiffs," 3 Sept. 1949.

97 Pratten, Man-Leopard Murders, 24; Frederick Cooper, Decolonisation and African Society: The Labor Question in French and British Africa (Cambridge: Cambridge University Press, 1996), 16.

98 Zachernuk, Colonial Subjects, 60.

99 Derek Peterson and Giacomo Macola, eds., Recasting the Past: History Writing and Political Work in Modern Africa (Athens: Ohio University Press, 2009), 11.

100 C. A. Bayly, Recovering Liberties: Indian Thought in the Age of Liberalism and Empire (Cambridge: Cambridge University Press, 2011), 13. 
"history in the Western mode became an, if not the, authoritative form of knowledge during the colonial period."101

Disputes over history were not new in Nigerian newspapers. But in the late 1940s they conveyed some of what people perceived to be at stake in the discussions about self-government. In 1948 Nigeria's new Governor, Sir John Macpherson, declared that the "Richards Constitution" of 1946, widely criticized by nationalists, would be replaced with a new constitution to be based on a massive consultation process with all Nigerians. Azikiwe and the NCNC generally supported a pan-Nigerian nationalism. But before the 1950s most nationalists, including the NCNC, proposed some form of territorial groupings and regional authorities of government. ${ }^{102}$ Regionalization was not rejected.

But what that looked like, exactly, was another story. Who belonged in which group or region? A spate of histories about Nigerian ethnic groups and cultures emerged in the $1940 \mathrm{~s}$ and $1950 \mathrm{~s} .{ }^{103}$ In addition to these pamphlets and booklets, newspapers debated local history in editorials, articles, and letters from correspondents. Letters in the "Readers' Platform," positioned on the same page as Hobo's "rovings," debated with each other the history of the Benin Empire; historical decisions about land between the Abrakas and the Ukwuani and whether the Abraka should be part of the Urhobo Native Administration; and whether any person speaking a dialect of the Edo language was a true Edo. On the latter issue, one reader argued that another article in the West African Pilot presented a false history designed to support "the ill-conceived three region idea." 104 These history debates, then, were interlinked with constitutional debates and with the question of subgroupings against a wider Nigerian nationalism. Before springing forth on his globetrotting on 9 July, Hobo argued that since the Igbo people's history showed "no record of capitulation to an outside force," Igbos should "revoke the past against the humiliations of today." The past, in other words, should be cancelled and the present reconstituted whereby Igbos would "run an efficient government of their own.", 105

When Hobo was "deputized" by the Hobo trust to report events in Paris, the column also debated world histories of imperialism. Hobo summarized the speech by delegate Gabriel d'Arboussier, the Senegalese communist, who rehearsed the communist line that war was the "inevitable consequence of the contradictions of the capitalist system in its imperialist stage."106 D'Arboussier posited a new "dawn" in history, that would only come through the

101 Purushotham, "World History," 10. For historicism and history in India, see especially Dipesh Chakrabarty, Provincializing Europe (Princeton: Princeton University Press, 2000).

102 Coleman, Nigeria, 308-28.

103 Ibid.

104 G. I. Osughe, "Readers' Platform: Who are the Edos?" Comet, 25 July 1949: 3.

105 "Sparks and Tiffs," 9 July 1949: 3.

106 Ibid., 5 July 1949: 3. 
complete abolition of capitalist imperialism, as had been achieved in the Soviet Union. If this was one interpretation of imperial history, Hobo added another. Complemented by editorials in the Comet, which denounced Europeans who manipulated history to further doctrines of racial superiority, ${ }^{107}$ Hobo read modern history as one in which Africans had been silenced by wars of aggression and destruction. Hobo juxtaposed the "prominent" African participation at the conference with the era of modern history during which, "Africans and peoples of African descent have without any say in the matter been subjected to the worst indignities of imperialist exploitation." In particular, Hobo recorded that the "voice of Africa" at the conference had declared a resounding "NO" to a future where Africans were drawn into "imperialist wars" without any say, as they had been in the past. Africans were no longer bystanders, observers in a world game in which they had no voice.

Both Hobo and Du Bois's emphasis on participation at this conference brings us back to the trope of flying and the composite genre of Roving Hobo's column. Reuters dispatches are standardized items, centralized and validated by the status and authority of the press agency and their metropolitan hubs. Yet while wireless dispatches appear to perform neutral news, Mikhail Bakhtin's theoretical work on language and genre tells us that these objectively neutral styles still function within frameworks of thought and worldview that correspond to a particular locale, class, and rhetorical tradition. ${ }^{108}$ Hobo's adaptation of wireless dispatches asserted their specialized knowledge of the addressee, repositioning the dispatches in a framework more conducive to a Nigerian audience. Hobo commandeered this vehicle of news and made it their own: this unconventional and inventive way of incorporating international news consecrated an alternative voice. And while Hobo was mainly the being who defied the laws of time and space through travel, the "we" of some of the column's greetings meant that readers participated in that movement. Zik press readers could inhabit the world in a central rather than peripheral capacity.

Yet there are important qualifications to this creativity. If Hobo's travels to Paris denounced the history of European imperialism in Africa, d'Arboussier's speech positioned another, ready-made historicism in its place, backed by Soviet foreign policy. And if Hobo discussed world historical narratives of imperialism and colonialism, readers disputed history closer to home. That correspondents debated local history while editorials and Hobo's column emphasized larger-scale histories of empire and race suggests that, as Harri Englund has recently shown in East African newspapers of the 1940s and 1950s, anti-colonial nationalism was not the only axis on which people conceived social and political change. Neither, importantly, should people's

\footnotetext{
107 Editorial, "We All Are Human Beings," Comet, 3 July 1949: 2. 98.

108 Mikhail Bakhtin, Speech Genres and other Late Essays (Austin: University of Texas, 1987),
} 
"horizons" be conceived as occurring in a binary between "local" or "nationalist" narratives. Rather, people made claims outside the confines of colonial idioms in provincial newspapers with cross-border readerships that reported on local events and personalities connected to non-local experiences. ${ }^{109}$ In Nigeria, newspapers contained many voices that disputed the past, present, and future within the colony and without. And alternative news formats like Roving Hobo and Tom Tinkle tacked across space and time, bringing to life one distinctive temporal frame for the present.

\section{CONCLUSION}

There are important differences between how Hobo and Tinkle play with timespace that might also distinguish the decades in which they wrote. Tinkle's panAfricanism is somewhat fleeting in how it expands and contracts, while Hobo's is more organized. It is based on associations and conferences. Both columnists destabilize time and space through their flight and their ubiquity. But Tinkle's anarchic, disordered present is not the same as Hobo's. Tinkle's columns disrupt the linear passage of time. It is not reversed, turned upside down in a manner that would simply also then invert the historical roles and power relations between peoples that had existed in the modern era of European imperialism. Instead, time becomes disordered, jumbled, and disturbed such that entirely different spaces of existence become visible. Hobo's fantastical ability to fly with his readers around the world also disturbs, defies, and in this sense disrupts the logic of time and space. But Hobo does this so that Comet readers can enter into a new historical present, one that has progressed to a new era that is more representative and egalitarian. In this sense, Hobo is more in line with other African "home-grown historians" and Indian "counterpreachers." This is less a disordering and more a conscious reordering of history that will recognize those previously excluded. In 1949-in the midst of constitutional negotiations that could lead to a greater slice of the political pie - order, not disorder, was important.

The writers discussed in this article were pseudonymous journalists rather than well-known historians or politicians. Their mobility allowed them to traverse time and space at various speeds and physical forms, but their columns were not specifically about time in any sustained way. They reported the news. They were tied to the mundane social and political agendas of the present. Yet the convergence of fantastical and absurd renderings of reality, modernity's "unstable" time, and colonial knowledge and power are undeniably visible in their writing. Their seemingly inane, gossipy columns have much to offer beyond their surface appearance. Their reporting indicates what "alternative languages of claim-making" actually looked like. The

109 Englund, “Anti Anti-Colonialism,” 232. 
physical and existential mobility of these pseudonymous authors served the "transitional" aspect of the call to create a citizenry of "Renascent Africans." This citizenry inhabited a time-space of specific and concrete planning but also a space that was contingent, changing, and at odds with present reality. Time and history was an unsettled and fluid space. By examining newspaper reports, we can attend in a different way to renderings of time and freedom. These were not narratives of alternative futures, nor were they futurist allegories of the present. Rather, the future is opened up to new possibilities by way of a tangled yet tangible present.

\begin{abstract}
Recent scholarship on Indian, African, and Caribbean political thinkers and leaders emphasizes the era leading up to and immediately after decolonization as one saturated with awareness of time and history. While much of this scholarship focuses on temporalities that open up the future, this article instead foregrounds imaginings of the present in the currency of news reports. By examining newspaper reports, we can attend in a different way to renderings of time and freedom. This article applies theoretical work on genre and addressivity to analyze how location, space, and time were simultaneously grounded and overcome by Nigerian newspaper columnists, and how this dynamic of bounded transcendence facilitated an array of social and political projects in the time-space of 1930s and 1940s colonial Nigeria. The pseudonymous writers examined in this article applied the trope of flying to exist in an alternate reality. Each "reporter" outstripped the normal logic of time and space through their ability to "jump" from place to place, and even to be in more than one place at once. By existing, as they claimed, "everywhere and nowhere" they literally and figuratively rose above the material reality of the everyday, thus ordaining an exclusive capacity for revelation.
\end{abstract}

Key words: Nigeria, temporality, genre, press, colonialism, modernity, panAfricanism, Azikiwe, Du Bois, surrealism 